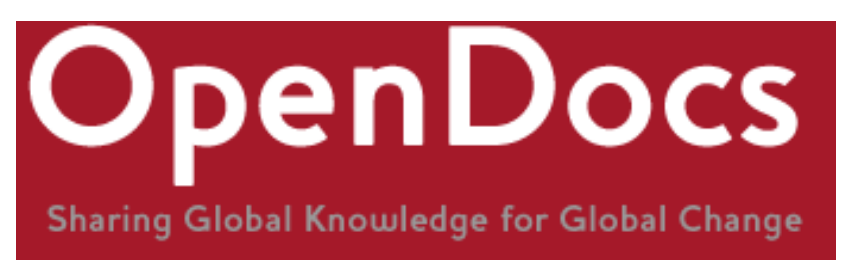

Title: The global politics of water grabbing

Citation: Franco, J., Mehta, L. and Veldwisch, G.J. (2013) 'The Global Politics of Water Grabbing', Third World Quarterly, Vol.34, No.9, pp.1651-1675.

Official URL: http://www.tandfonline.com/10.1080/01436597.2013.843852

More details/abstract: The contestation and appropriation of water is not new, but recent global debates on land grabbing are bringing increased attention to a water perspective in these discussions. Water grabbing takes place in a field that is plural-legal, both locally and globally. Formal law has been fostering grabs, both in land and water. Meanwhile, today's formal water and land management have been separated from each other - an institutional void that makes encroachment even easier. Ambiguous processes of global water and land governance have increased local level uncertainties and complexities. Powerful players can navigate their ways through such uncertainties, making them into mechanisms of exclusion for poor and marginalised people. As in formal land management, corporate influence has grown in water management. For less powerful players, resolving ambiguities in conflicting regulatory frameworks may require tipping the balance in favour of the most congenial one. Yet compared to land governance, global water governance is today relatively less contested from an equity and water justice perspective, even though land is fixed, while water is fluid and part of the hydrological cycle - and therefore water grabbing potentially affects greater numbers of diverse water users. Water grabbing can be a powerful entry point for contestation, which is needed to build counterweights to the neoliberal corporate business led convergence in global resource governance discourses and processes. Elaborating a human right to water in response to water grabbing is urgently needed.

Version: Submitted version (Author's Original Manuscript)

Terms of use: This is an Author's Original Manuscript of an article whose final and definitive form, the Version of Record, has been published in Third World Quarterly (2013) copyright Taylor \& Francis, available online at:

http://www.tandfonline.com/10.1080/01436597.2013.843852

This is a download from OpenDocs at the Institute of Development Studies

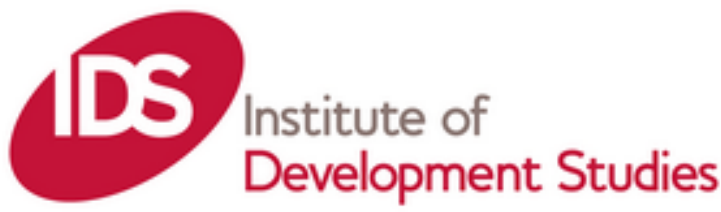




\title{
The Global Politics of Water Grabbing
}

\author{
By Jennifer Franco, Lyla Mehta and Gert Jan Veldwisch
}

\begin{abstract}
The contestation and appropriation of water is not new, but recent global debates on land grabbing are bringing increased attention to a water perspective in these discussions. Water grabbing takes place in a field that is plurallegal, both locally and globally. Formal law has been fostering grabs, both in land and water. Meanwhile, today's formal water and land management have been separated from each other - an institutional void that makes encroachment even easier. Ambiguous processes of global water and land governance have increased local level uncertainties and complexities. Powerful players can navigate their ways through such uncertainties, making them into mechanisms of exclusion for poor and marginalised people. As in formal land management, corporate influence has grown in water management. For less powerful players, resolving ambiguities in conflicting regulatory frameworks may require tipping the balance in favour of the most congenial one. Yet compared to land governance, global water governance is today relatively less contested from an equity and water justice perspective, even though land is fixed, while water is fluid and part of the hydrological cycle - and therefore water grabbing potentially affects greater numbers of diverse water users. Water grabbing can be a powerful entry point for contestation, which is needed to build counterweights to the neoliberal corporate business led convergence in global resource governance discourses and processes. Elaborating a human right to water in response to water grabbing is urgently needed.
\end{abstract}

\section{Introduction}

The contestation and appropriation of water is not new, but in the contemporary context of a convergence of changing global dynamics around food, climate, energy, and finance, and the resulting global debates on land grabbing, there is renewed interest in a water perspective on resources grabs. ${ }^{1}$ Increasing attention to water has the potential to (re)invigorate inquiry and action along two lines simultaneously: 1 . by casting new light on the global land grab phenomenon itself and related issues of land governance, while, 2. opening up new windows on old questions of political control, social justice and environmental sustainability in relation to use and management of water. Since about 2010 evidence has been growing that the rush to control water resources is an important cause, as well as effect, of the phenomenon now commonly known as land grabbing. Specific attention to water grabbing has been prompted by the observation that while land grabbing has received a lot of attention, 'water as both a target and driver of this phenomenon has been largely ignored despite the interconnectedness of water and land'.

In recent years various studies have put forward strong evidence for understanding land grabbing for agriculture (for food, feed, fuel and raw material for 
industrial use) as having important water dimensions. To illustrate, in many parts of sub-Saharan Africa rainfall is too erratic for high investment into agricultural production without securing access to reliable water. This is one of the reasons why land grabbing for agriculture almost per definition includes water grabbing, even when not explicitly specified in the land deals.;4 Globally most agricultural production is based purely on rainwater that has locally infiltrated the soil (so called 'green water'), but diverted surface water and pumped-up groundwater (the so called 'blue water') is a far more reliable source for commercial agricultural production. ${ }^{5}$ Hence the proliferation of political narratives such as 'unexploited and underutilised' land and water resources, how they 'need' new and large scale investment to 'unlock' their potential and to awaken Africa's 'sleeping giant' and promote a blue revolution in Africa. ${ }^{6 ; 7}$ Even when investment plans do not specify requirement for water beyond rain, experience shows that additional water will have to be mobilised for the crops to do well and this may typically be in the most water-scarce period and in competition with existing and/or potential future uses. ${ }^{8 ; 9 ; 10}$

Beyond agriculture, water grabbing extends into the water, energy, climate and mineral domains in ways that highlight the distinct material character of water. In short, water may be the context of a grab, it may be the object of a grab, or it may be both at the same time. To illustrate, in agriculture-driven grabs, water is a crucial context for land grabbing - determining for example 'which land located where' is desirable or most coveted by investors, usually having some irrigation potential. Water can also then become the object of what is primarily an agriculture-driven land grab. ${ }^{11}$ In other cases water itself is the primary object of the grabbing, resulting in reallocations of formal and informal water rights and their benefits of use. For example, hydropower development in Turkey is made possible through neoliberal reforms that transfer exclusive access rights to hundreds of rivers and streams to private companies for 49 years. ${ }^{12}$ In Cajamarca, Peru, large-scale private mining operations are prompting big changes in how water rights are allocated, leading to detrimental changes in the amount and quality of water available to downstream users. $^{13}$

As these diverse examples suggest, while land and water are interconnected, a focus on the grabbing of water resources helps to bring out an additional, distinct set of issues that are linked to the materiality of water. For instance, water availability fluctuates across time and space, flows within watershed boundaries and often has pronounced dislocated (downstream) effects, in terms of quantities and qualities. Moreover, a focus on the grabbing of this materially distinct and finite natural resource also uncovers some additional analytical complexities with regard to water that have big implications for both policy and political action. For example, it is very difficult to pinpoint (the effects of) reallocations, amongst others, due to surface water/ groundwater interactions and inter-annual variability, which in some settings has important 'spillover' implications for policy and political action. ${ }^{14}$ Meanwhile, in other settings, pointing out the threat of reallocation of a natural resource that is so crucial for human life may be enough to generate political resistance. The fluidity of water thus both complicates and potentially enriches the picture on land grabbing, both analytically and empirically - something which researchers looking at the contemporary global enclosures are just beginning to explore.

With these issues and the ongoing build-up of water-grabbing focused case material in mind, we find this to be a good moment to take a more systematic look at land and water governance - especially at the global level - to see where we are in terms of generating knowledge and insights that have relevance for policy and 
political action. The global level of water related governance mechanisms is emphasised here as it has largely been absent in the discussions on the new global enclosures. The mechanism and processes through which water grabbing takes shape in practice, such as the everyday politics and the role of water technologies, would also deserve further scrutiny and theorisation, but are outside the focus of this current article. Our analysis builds on discrete policy discussions over uneven access to and control of water that go back decades and are not necessarily linked to or coterminous with the agrarian question in which much land grabbing research is framed. Meanwhile, some of the more land oriented global governance discussions, which likewise go back decades, are virtually silent on the question of water. Land and water are interconnected, but not the same, and their management and governance have been constructed often in isolation from one another historically. There are 'land experts/activists' and there are 'water experts/activists', and seldom do the two synergise in matters of governance. Bringing water issues to the fore in this context thus involves more than simply adding water to the land grab/ land governance debate and stirring. It requires taking stock of ongoing debates around discrete questions of water rights, water management, the right to water and water governance, in both the land and water domains, and exploring how these potentially inform and eventually re-forge the current global debate on land grabbing into a broader and more integrated understanding of land-water issues and governance. Such an understanding is needed in order to build political contestation toward eventually tipping the balance of power in the direction of social and environmental justice. This article aims to contribute to a deeper understanding of these issues. We begin by defining how we understand water grabbing before exploring the tendency towards neoliberal processes in disparate global land and water governance mechanism that facilitate resource grabbing. We chart the specific neoliberal turn in water management, growing corporate influence in global policy making around water and how seemingly neutral processes such as Integrated Water Resources Management (IWRM) can serve powerful players' interests. We conclude with some thoughts of how social justice perspectives around land and water grabbing processes can be advanced.

\section{Understanding Water Grabbing}

Water grabbing is a process in which powerful actors are able to take control of, or reallocate to their own benefits, water resources used by local communities or feeding aquatic ecosystems on which their livelihoods are based..$^{15}$ It is one manifestation of a wider global trend today involving large scale (re)allocations of natural resources more generally. Drawing insight from the discussion on land grabbing, we understand water grabbing as the capturing of control not just of the water itself, but also of the power to decide how this will be used - by whom, when, for how long and for what purposes - in order to control the benefits of use. The fast growing case material on land grabbing shows a wider contemporary trend or cycle taking place in the context of the intersection of global changes in the food-feed-fuel system, in climate, and in global finance and economy, which is driving the further expansion of capitalist control over natural resources on a large scale, for purposes of production, extraction, and speculation. As many analysts and observers have noted, capture of land and water resources by powerful actors is nothing new, but has been happening since centuries. It is useful to situate and analyse different episodes of appropriation in their 
particular historical and institutional context. The current cycle is what we refer to as land and water grabbing.

A key feature of this phenomenon is that the underlying business deals are large scale, most visibly in terms of land area and capital involved. There is a strong tendency in the literature on land grabbing to try to define land grabbing mainly in terms of the physical size of the land acquired. ${ }^{16 ; 17}$ By incorporating scale of capital into the analysis, land, water and other resources become visible as central in the operation of capital. A purely land-centred view overlooks the underlying logic and operation of capital accumulation. ${ }^{18}$ For water grabbing, the fixation on size has a parallel in a too narrow focus on the volume of water involved, ignoring that access to water concerns distribution in time and space. ${ }^{19}$ Hertzog et al. ${ }^{20}$ in their study of water grabbing in the Office du Niger, demonstrate how important it is to thoroughly assess water requirements in space and time, rather than just looking at water volumes. This also suggests a need to seriously take into account the notion of scale with regard to flows of water, in order to make visible and account more systematically for changes in water distribution and water quality.

We will return to this point later. For now it is useful to point out that our approach to water grabbing dialogues with the work of Borras et al. and is likewise grounded in a combined political economy, political ecology and political sociology approach. ${ }^{21}$ As such, it seeks to move beyond narrow, proceduralist mainstream understandings of the 'grabbing' as illegal by definition, which have the disadvantage of emphasising the formal-legal quality of the transaction and from there limiting the lens on grabbing to only those cases where state law is clearly contravened. Such an approach is problematic.

First, it tends to dismiss deeper interrogation of the actual nature and desirability of the outcomes of these 'transactions' in terms of the underlying development model that the new economic arrangements usher in, including, as pointed out by Borras and Franco, changes in land use and land property relations that often entail dispossession and ecological destruction. ${ }^{22}$ How large-scale land and water grabs are prompting similar changes in and undermining existing use, management and social relations of water, has recently been explored by (among others): Williams et al. in Ghana; ${ }^{23}$ Bues and Theesfeld in Ethiopia; ${ }^{24}$ Houdret in Morocco $;{ }^{25}$ Duvail et al. in Kenya; ${ }^{26}$ and Velez Torres in Colombia. ${ }^{27}$

Second, it tends to reduce the transaction itself to essentially a technical formal-legal procedure, at times even conflating financial accounting with political accountability, and thereby underestimating (or ignoring) how the grabbing of natural resources is taking place in a historical-institutional field that is plural-legal and marked by power asymmetries and thus deeply political, and that in many settings it is formal state law that has been fostering the grabs. For land, Wily shows how formal law that is supposed to protect vulnerable people can in practice 'oppress and dispossess' ${ }^{28}$ On the water front, recent research shows how powerful actors use legal means as well as technical definitions to divert water and the benefits of its use away from local communities. In India, sectoral reforms are used as a mechanism to legalise and legitimise water grabbing processes. The state also takes advantage of the obscurity in the policy regime and when challenged on legal grounds, reform instruments are blatantly redefined. ${ }^{29}$ In many cases, state organisations bend or reinterpret existing rules and regulations that should actually prevent water grabbing, as in the case of Ethiopia where the Water Resources Management Proclamation is supposed to protect local users. ${ }^{30}$ In other cases, in various ways, legally required 
Environmental Impact Assessments (EIAs) have served as mechanisms for 'window dressing' water grabbing activities. ${ }^{31 ; 32}$

All these studies show that a litmus test of 'legality' ultimately offers little traction when trying to determine what counts as water (or land) grabbing. In fact, grabbers often make use of legally complex situations around water tenure. New commercial users usually coexist with complex non-registered users who are invisible. This legal pluralism can be both enabling and disabling, but it is often very difficult for local users to defend their claims. Companies often strengthen their informal social and political networks to influence governance processes. Hertzog et al. refer to the latter as 'a fragmented negotiation process, whereby different investors have used different networks in the administrative and political apparatus in order to secure both suitable land and water arrangements'. ${ }^{33}$ Meanwhile, formal water and land management are often separated from each other - an institutional void that also makes encroachment easier and the separation of land and water rights can contribute to creating space for water grabbing to occur. ${ }^{34}$

Stepping back, one finds that water grabbing (like land grabbing) is diverse in its appearance. Water grabbing 1 . is driven by varied forms of state-capital alliances, 2. is not limited geographically, 3. happens in diverse agro-ecological contexts, 4. is unfolding across various water-land property rights regimes and 5. is leading to diverse impacts. Each of these points is elaborated below using recent water grabbingfocused case study material.

First, the main actors behind diverse grabbing processes are varied forms of state-capital alliances, and involving varied types of mechanisms and processes that are serving to make the grabs possible - among others: 1. State law and policy reforms; ${ }^{35 ; 36}$ 2. State law and new policy interpretations; ${ }^{37 ; 38} 3$. Violation of state law; ${ }^{39 ; 40}$ 4. New public-private interest business coalitions, ${ }^{41 ; 42 ; 43} 5$. Exploiting legal complexity; ${ }^{44 ; 45}$ and 6. Bypassing democratic accountability processes. ${ }^{46}$

Second, water grabbing, like land grabbing, is happening across the globe. Many of the most prominent reports and studies, including Woodhouse, ${ }^{47}$ Woodhouse and Ganho, ${ }^{48}$ Skinner and Cotula, ${ }^{49}$ tended to focus initially on water grabbing happening in Africa, perhaps reinforcing the impression (cultivated in the media) that it was a mainly African phenomenon. But empirical evidence shows the unfolding throughout Latin America; ${ }^{50 ; 51}$ across Asia,${ }^{52 ; 53}$ in the Middle East and in Eurasia as well..$^{5455}$

Third, water grabbing is also happening across various agro-ecological contexts: river deltas and floodplains, inland rivers, freshwater lakes, wetlands, as well as semi-arid plains and savannah. And fourth, water grabbing, like land grabbing, is happening across diverse property rights regimes, including commons such as grazing corridors like in the Tana Delta case,${ }^{56}$ communal/ community tenure and resource management systems, $;^{57 ; 58 ; 59 ; 60}$ land- and waterscapes understood by local communities as territory; ${ }^{61 ; 62}$ and areas under individual private property rights regimes. ${ }^{63 ; 64}$

Finally, the impacts of water grabbing are diverse. The impacts of land grabbing have been distinguished in two broad types: exclusion and adverse incorporation. ${ }^{65}$ However, water grabbing and its impacts appear to be even more diverse and 'slippery' due to its dislocated, timing-relevant and quality-related effects. ${ }^{66}$ Interventions in the water cycle can for instance 1 . disturb the amount of groundwater and downstream water available for existing users (exclusion from the volume), 2. change the peak and base flows (exclusion in timing), 3. change the agroecological landscape (exclusion from ecosystem benefits that require, for example, 
occasional flooding), and 4. affect the quality of the water (exclusion from clean and safe water). For the latter, water grabbing does not necessarily involve diversion of water, but rather pollution of water resources by powerful upstream actors, in a process marked by the externalisation of problems and costs (which are transferred from the causers to local communities downstream. ${ }^{67 ; 68}$ These 'watery' types of exclusion could also be understood in terms of adverse incorporation - i.e. imposing water use and management regimes that directly or indirectly 'incorporate' people into changed water regimes tied to the new economic arrangements.

\section{Global Land and Water Governance}

Water grabbing takes place in a field that is plural-legal - i.e. characterised by the coexistence of varied and diverse regulatory frameworks and processes shaping who gets what kind of access to which water resources and for what purposes. As seen in the previous section, much of the empirical work of recent years emphasises this point from a local perspective. ${ }^{\text {a }}$ But legal pluralism characterises the 'higher' levels of the political system too, including the global level where plural-legal resource 'governance-scapes' are becoming increasingly apparent. This is certainly the case in the land and water domains. As Mehta et al argue, '...the multiplication of institutional forms and sites of environmental governance and natural resource management itself generates greater uncertainty as individuals, social groups, and organisations jostle for control over resources and their futures. The result is both that conventional theoretical divides between local and global, formal and informal have been made redundant, and that ambiguity, complexity and uncertainty increasingly characterise the conditions under which resources are governed and managed'.69 Powerful players can navigate their ways through such uncertainties, making them into mechanisms of exclusion for poor and marginalised people, and facilitate grabbing processes.

In this section we review the main global processes that govern and attempt to regulate water access, use and distribution of benefits and burdens of these. We describe this scene in terms of an ongoing build-up of structures, institutions, and discourses. This has been happening in a fragmented fashion historically, resulting in separate regulatory activities that are relatively unconnected. The discussion traces their disparate trajectories and tries to reveal what each may be contributing to regulating water grabbing. We argue that these global level ambiguities are reinforcing an overall regulatory setting which is highly permissive to water grabbing when political contestation from a social justice perspective is either weak or absent.

Globally, numerous competing governance mechanisms have emerged around the issue of global capital engaging with local natural resources. High profile governance initiatives addressing land use, management and access in relation to agriculture thus include, among others: 1. the World Bank led 'Principles of Responsible Agricultural Investment' or PRAI; 2. the Food and Agriculture Organization of the United States (FAO) based 'Voluntary Guidelines on the Responsible Governance of Tenure of land, fisheries and forests in the context of national food security' or FAO-TG; 3. the ongoing FAO- Responsible Agricultural

\footnotetext{
a A legal pluralism lens helps to situate law as a complex and contested socio-political process that unfolds unevenly over time and space and generates variable and contingent results that are open to competing interpretations.
} 
Investment, or FAO-RAI process, and 4. more lately the G8's 'Land Transparency Initiative' or G8LTI. None of these initiatives deal much or at all with issues of water access, use and distribution of benefits and burdens. Although 'land tenure security' is a major concern in all of these initiatives, they are not necessarily referring to the same thing, while at the same time land remains the main focus of regulation. Despite the growing visibility of water grabbing these agriculture-oriented governance initiatives have tended to neglect a wide and deep range of issues related to water.

The highly contentious political process that led to the recently adopted FAOTenure Guidelines (FAO-TGs) warrant special attention since it constitutes the most recent site of struggle in the 'proxy war' between competing views and interpretations of natural resources. ${ }^{70 ; 71}$ The FAO-TGs mark an important step forward in elaborating a human right to land as they are 'the first international instrument which applies an ESC-Rights based approach to the governance of land'. ${ }^{72}$ Though the understanding of land in these guidelines has its problems and contradictions, the situation is even worse with respect to water, since water was excluded from coverage. ${ }^{\mathrm{b}}$ During the final negotiations, the effort by civil society to get water into the guidelines ran up against opposition and resistance from other participants who denounced water and water governance as 'too complicated'. ' For whatever the FAO-TGs are worth, this poses a major ambiguity since water is indeed deeply and inextricably interconnected with other natural resources. ${ }^{\mathrm{d}}$

The FAO-TGs and other agriculture-oriented governance initiatives have emerged against the backdrop of competing (and still evolving) international regulatory frameworks. One of these competing frameworks is international human rights law, which served as a crucial source of inspiration, guidance and support to the civil society delegation throughout the FAO-TG formulation process, while seeming to provoke much discomfort and disdain from some government delegations. Although there is still a long way to go and progress has been uneven, international human rights law has been slowly moving toward authoritative establishment of land, water and associated resources such as fisheries and forests as matters of human rights. This has for instance led to the inclusion of access to land as part of "the right to feed oneself'. ${ }^{73}$ Although there is as yet no distinct human right to land, the pressure to establish such a right remains. ${ }^{74}$ There is a globally recognised right to water but it remains conceptually ambiguous and so far has had limited value in being a countervailing force against grabbing processes.

The human right to water was the result of decades of intense global struggle and lobbying, as it was initially resisted by powerful players in the water domain and countries such as Canada and the USA. It was not explicitly recognised in the 1948 Universal Declaration of Human Rights and subsequent declarations. In July 2010, the UN General Assembly and later in September 2010 the UN Human Rights

\footnotetext{
b No mention of water is made beyond a single reference to the governance of water and other "associated natural resources", such as for instance fisheries, by national states on basis of their own "different models and systems of governance" (Committee on World Food Security (CFS) and FAO, 2012: iv).

c One of the authors was present when the proposal to include water was voted down by the governments as being "too complicated".

d This leaves small scale fishers vulnerable to other governance initiatives, which have the potential to facilitate "ocean-grabbing" (see World Forum of Fisher Peoples (WFFP) and World Forum of Fish Harvesters and Fish Workers (WFF) 2013 "Call for Governments to Stop Supporting the Global Partnership for Oceans (GPO) and Rights-Based Fishing (RBF) Reforms", available at: http://masifundise.org.za/press-statement-by-the-world-forum-of-fisher-peoples-in-response-to-theglobal-partnership-for-oceans/).
} 
Council, finally recognised access to clean water and sanitation as a human right. This official recognition was a great victory for the global water justice movement and has been used as a powerful mobilising tool for water struggles all around the world.

South Africa, Ecuador, Bolivia, Gambia, Tanzania, Uruguay and others have recognised the human right to water, thereby committing to respect, protect and fulfil the right of access to safe and affordable domestic water services. But all over the world there remains a considerable gap between human rights talk and human rights practice and governments are usually constrained in their financial commitments to achieving universal access to water and sanitation. There is often a clear tension between a government's commitment to rights and to market-based mechanisms, with the latter tending to prevail. Bolivia, for example, has been at the forefront of international campaigns to recognise the human right to water. Yet, domestically, the Morales government has been criticised for pursuing economic development policies based on industrialisation and extractive industry expansion that are elite-driven and often violate local people's human rights to water and water rights. ${ }^{75}$ South Africa was the first country to provide constitutional recognition of the human right to water and in 2001 the Free Basic Water Policy was introduced, which aimed to provide a basic supply of water to all households free of charge. At the same time, the South African water policies were also informed by market-driven approaches to water management, including an emphasis on cost recovery, user fees for water and controversial cut offs which have violated poor people's basic rights to water. ${ }^{76}$

Human rights, like any rights, are open to interpretation, which makes ensuring a social justice interpretation a matter of political power and strategic political action. In the case of the human right to food, the office of the UN Special Rapporteur on the Right to Food has traditionally served as an important rallying point for civil society organisations and social movements seeking to realise a social justice interpretation. By contrast, the UN Special Rapporteur on the Right to Water has taken a quite different approach, issuing reports stating that 'the human rights framework does not express a preference over models of service provision' and that 'human rights are neutral as to economic models' ${ }^{77}$ Thus, it is not surprising that big global water corporations such as Suez have publicly declared that they 'strongly believe' in the right to water. ${ }^{\mathrm{e}}$ So far the human right to water has not been deployed to countervail water grabbing processes, partly because of its limited scope to domestic, rather than productive uses of water. Unlike the UN Special Rapporteur on the Right to Food, who has frequently commented on land grabs, the UN Special Rapporteur on the Right to Water has been reluctant to engage with water grabbing issues.

The other main competing international regulatory framework is being consolidated in an array of free trade agreements (FTAs) and bilateral trade agreements (BITs) building on legalist corporate business law discourses, principles, definitions and their underlying assumptions. Many social and environmental justice activists working on a wide range of concerns see these trade agreements as fundamentally at odds not only with human rights law, but also with democratic governance more broadly. They complicate national efforts to regulate environmental, labour, domestic content questions and treat national legislation on these matters as measures in restraint of trade, which are potentially actionable in the dispute resolution mechanisms of the FTAs or World Trade Organisation (WTO). ${ }^{\mathrm{f}}$ The rise of

\footnotetext{
${ }^{\mathrm{e}}$ http://www.suez-environnement.com/water/challenges/promoting-access-water-sanitation/ Accessed May 1, 2013

${ }^{\mathrm{f}}$ Thanks to an anonymous reviewer for pointing out the latter perspective.
} 
a corporate-business law agenda in recent decades results from the project to institutionalise and consolidate neoliberalism internationally by strengthening markets while shrinking states, ${ }^{78}$ and is expressed through law and policies on trade and investment, which 'play a crucial role in building the global supply chains that are part of the modern international economy'. ${ }^{g}$ Narratives that justify land and water grabbing play an important role in facilitating these processes. In addition to the narrative of 'marginal' and 'idle' lands as 'underexploited resources', there is also the 'economic scarcity' narrative. Such narratives have been serving to justify the involvement of the private sector in irrigation on the twin argument that public funds are short while private funds are more efficient with regard to water use. Since the 1990s, FTAs and BITs have been opening up new opportunities for foreign investors to bypass national laws and to question proposed government regulations before international tribunals if profits are threatened. National governments are known to refrain from (or resist) enacting human rights-based social and environmental regulation within their own borders. Linked to these developments are the reforms of the water and energy sectors promoted by multilateral and regional banks encouraging privatisation and deregulation, often in the name of efficiency.

If the most prominent contemporary global governance mechanisms shaping the land domain today offer little concrete guidance or practical insight on how to deal with land and water grabbing, neither do the main global governance mechanisms that exist more specifically for water. Contemporary water governance at the global level is an arena arguably characterised by a higher degree of ambiguity resulting from competing formal-regulatory actors and official processes, with few agreed rules or procedures regarding decision-making. Even the UN Watercourses Convention, the global water convention specifically related to the governance, use and management of watercourses has not been ratified by sufficient countries to enter into force. ${ }^{\mathrm{h}}$ Because there are very few formal agreements, there is no single clear-cut global water regime with agreed-upon rules of the game providing normative prescriptions, clear expectations and institutionalised relationships. ${ }^{79}$

Partly this is because water is not really a global issue or a 'global public good'. Despite the existence of the global hydrological cycle, water remains highly localised or at best regional in scope. Water availability is variable across time and space and dependents on factors such as climate, season and temperature, making it very difficult to provide blanket statements and solutions regarding the global state of water. Access to water between countries, within regions and countries, and between women and men is highly unequal and water shortages affect different social groups differently, whilst hitting the poorest the hardest. Even though the 'global' nature of water is difficult to capture, and there is no single overall clear-cut global water regime, there is nonetheless an emerging global water regime (ibid) ${ }^{80}$ This emerging water governance regime at the global level could best be described as plural-legal, encompassing several separate regulatory orders, each with its own field of action and institutional logic. Examples at the global level include the dams movement, convergences around the neo-liberalisation of water, international consensus around Integrated Water Resources Management (IWRM), and the water footprint discourse.

It is relevant to briefly look more closely here at the water footprint discourse. In assessing water grabbing, 'water footprint accounting', which demonstrates flows of 'virtual water' as 'embedded' in products, has been suggested as a useful tool. ${ }^{81}$

g Seattle to Brussels Network, 2012, p.22

${ }^{\mathrm{h}}$ www.gcint.org/what-we-do/water-peace/un-watercourses-convention, accessed 1 May 2013. 
But water footprint tools have not included the political nature of water distribution, especially at the local level. ${ }^{82}$ For instance, water footprint accounting does show that through the import of Peruvian asparagus large amounts of virtual water is imported, ${ }^{83}$ but it does not differentiate between an asparagus produced under industrial agriculture with devastating effects on the local economy and depleting a nonrenewable aquifer on the one hand and an asparagus produced under robust family farming with renewable (rain)water. ${ }^{84}$ In that respect water footprint accounting has very limited value in the assessment of global water grabbing and in some cases, they could even facilitate grabbing processes due assumed 'higher water productivity'.

Zooming back out to look at the broader picture, each of the different global regulatory orders for water have their own networks of experts, including economists, engineers, policy professionals, consultants and so on. Many supra-national organisations such as the World Commission on Dams, the World Water Council (WWC) and the Global Water Partnership (GWP) are currently addressing global problems and issues concerning water. Even though UN agencies have water programmes, there is no one major UN agency devoted to water and the one that does exist, UN Water, established in 2003 as a UN inter-agency coordination mechanism, remains a virtual institute with little influence. The GWP was founded in 1996 to champion the case of IWRM around the world. The World Water Council is a controversial elite international body based in Marseille established by the World Bank and members from French water companies operating around the world and other water policy experts. Added to the mix, is the current engagement of corporate players in water management, playing a key role in determining water security and insecurity. Even though these supranational organisations lack global legitimacy, they are powerful in shaping dominant debates and on-going processes.

Amidst increasing complexity and uncertainty, disparate global processes are interacting in a mutually reinforcing way to shape the way land and water are being allocated and reallocated. This is seen especially around processes of commodification and financialisation of natural resources, with land and water grabbing as both cause and effect. ${ }^{85 ; 86 ; 87}$ This process has been termed liberal environmentalism or market environmentalism. ${ }^{88 ; 89}$ Land and water are increasingly taken strictly as an economic asset, either in productive, extractive or speculative directions. The convergence is therefore a reflection of the ideological ascendancy of neoliberal corporate power across domains. There is a danger that this leads to the establishment of an overarching global legal framework for natural resources that 'secures' rights to these from a corporate-business/investor-protection perspective. Recent debates around the 'securitisation of the environment', accompanied by talk of future threats to human security and the 'food-energy-water nexus' that is driving new hydropower and energy developments and promoting the inclusion of new corporate players are all pointing in this direction.

\section{Privatisation, commodification and water reforms}

In this section we look more closely at global processes that are interacting to shape the way water is allocated and reallocated and water grabbing is taking place. We do this by sketching the historical background of what marked the neo-liberal turn in the water sector: the Dublin declaration and the subsequent processes of water privatisation, commodification and eventually also its financialisation (section 4.1). 
The discourse of Integrated Water Resources Management (IWRM) and its key principles have become highly influential all over the world. The ways in which IWRM policies and principles can form the playing field through which many of the water grabs take shape are elaborated in section 4.2. In section 4.3 we conclude with a discussion on the growing influence of the corporate sector.

\section{. From Delhi to Dublin and the neoliberal turn in water}

Water has been the focus of global collective action. Yet, despite repeated principles, declarations and meetings nearly 800 million people lack access to safe water for drinking. The Mar del Plata Conference (1977) was the first - and still the only global conference on water held under United Nations auspices. This led directly to the UN 'Water Decade' (1981-1990) which aimed at achieving universal coverage to drinking water and sanitation by 1990. At the end of the decade the target remained far off. To assess what had happened and to look towards future pathways for collective action, in 1990 the UN held a global consultation in New Delhi hosted by the Indian Government. Under the slogan, 'Some for all rather than all for some', the New Delhi Statement stressed (1) Protection of the environment and safeguarding of health through the integrated management of water resources and liquid and solid wastes (2) Institutional reforms promoting an integrated approach (3) Community management of services, backed by measures to strengthen local institutions and (4) Sound financial practices, achieved through better management of existing assets, and widespread use of appropriate technologies. ${ }^{90}$

The New Delhi Statement, with its focus on equity and universality, was rapidly overshadowed by the 'Dublin Statement' of 1992 - an important turning point in the global discourse on water governance. The statement emerged from the International Conference on Water and the Environment (ICWE) held in Dublin in January 1992. It was organised by water experts and held under the auspices of the World Meteorological Organization. The conference culminated in the formulation of the Dublin principles which recognised (1) the finite nature of water and its key role in sustaining life, development and the environment; (2) the importance of participatory approaches in water development and management; (3) the central role played by women in the provision, management and safeguarding of water and (4) the economic and competing values of water and the need to recognise water as an economic good (International Conference on Water and the Environment, 1992). It is this fourth principle that has made Dublin a focus of policy differences and global fault lines ever since. Declaring water an 'economic good' in Dublin remains to this day deeply controversial. Many in the global water community still feel this not only legitimises the 'commodification' of a life-giving resource, but also continues to justify potential privatisation and resource capture (including water grabs). Strictly speaking, 'economic goods' are goods that are scarce and legitimise human action and market intervention. ${ }^{91}$

The controversial declaration of water as an economic good must be seen as a logical next step from the sustainability paradigm that has its roots in the late 1970s in combination with the neo-liberal turn to economics more generally. The sustainability perspective amongst others raises the question of financial sustainability, i.e. the ability to generate finances to sustain and maintain a particular use. But there are some water needs and uses that lie outside the gamut of economic valuation. By its focus on water as an economic good, Dublin provided a solid building block for a 
global discourse that evaluates water distribution in the first place on its economic value.

Corporate agriculture, mining, hydropower and other capital intensive economic activities are often seen as more important contributors to economic growth than smallholder agriculture, community drinking water and traditional fisheries. The latter may have a place in national development policies, but usually are then framed within the realm of 'subsistence' rather than being seen as sectors that can provide a long-term sustainable contribution to a country's development. In other cases peasant agriculture and traditional fisheries are completely ignored and the areas in which these are important declared 'vacant', 'unused', 'empty' or at least 'underutilised'. For Mozambique Beekman and Veldwisch demonstrate how discourses and policies that favour foreign direct investments over investing in smallholder agriculture encourage local water grabbing processes. ${ }^{92}$ There are many other cases in which these dichotomies between smallholders and commercial investments are well observable in national processes, policies and discourses. ${ }^{93 ; 94 ; 95}$

The shifts in paradigms around water provision and management as expressed in the Dublin statement must be viewed in conjunction with the rise of the neoliberal agenda of the early 1990s which entailed a shift away from viewing governments as responsible for poor people's needs and problems. Instead, the state was required to play a facilitating and regulatory role without direct engagement. The Washington Consensus of the 1990s thus saw changes in how basic services such as water were governed, which included budget cutbacks, privatisation and de-regulation often legitimised through processes of economic liberalisation and structural adjustment. After Dublin the World Bank began to play a central role in water and sanitation and water has moved away from being viewed as a common good and a public service to a commodity that is being managed according to economic principles. ${ }^{96}$ This led to controversial water privatisations around the world, details of which cannot be discussed here. ${ }^{97 ; 98 ; 99}$

Twenty years on from the Dublin Conference, we are witnessing the privatisation not just of the service and infrastructure but of the resource itself. In recent years, water is being transformed into a commodity tradable on large scale global markets through water trading schemes - leading to the financialisation of water resources and the management of water in the hands of financial markets. ${ }^{100} \mathrm{In}$ Chile it has been possible to buy and sell different types of water rights since 1981 and its water market is considered an important policy model on which various other countries, such as Mexico, Argentina and Morocco have based their policies. ${ }^{101}$ In Uganda, the controversial Bujagali dam, which is being resisted by local communities around the Nile, is being financed by the hedge fund Blackstone in partnership with the World Bank and the European investment bank. ${ }^{102}$ These and other examples highlighted in this section have outlined the diverse trajectories of neoliberalism that have led to the dominant discourse of water as an economic and tradable good whose market value supersedes its cultural and social values.

\section{IWRM: Fluidity of a concept}

The concept of Integrated Water Resource Management (IWRM), as practised around the world since about two decades, emerged as an elaboration of the 1992 Dublin principles. The most frequently used definition of IWRM comes from the Global Water Partnership and is defined as 'a process which promotes the coordinated 
development and management of water, land and related resources, in order to maximise the resultant economic and social welfare in an equitable manner without compromising the sustainability of vital ecosystems' ${ }^{103}$ Despite these laudable aims, IWRM is rather a vague, diffuse and amorphous concept and it remains unclear what should be integrated and by whom. ${ }^{104}$ However, it still remains a highly attractive concept precisely because of its capacious nature which provides a lot of space for interpretation and due to its ideal typical nature of what good water management should look like. ${ }^{105}$

IWRM seeks to achieve a maximisation of Economy, Equity and Ecosystems. However, it is rarely acknowledged that these goals are often 'antagonistic [..], that 'trade-offs are necessary and hard to achieve in such situations'. ${ }^{106}$ IWRM thus 'obscure[s] the political nature of natural resources management; and [is] easily hijacked by groups seeking to legitimise their own agendas'. ${ }^{107}$ All this can make IWRM an apolitical cloak for processes that are deeply transformative and involve the re-allocation of limited water resources. In what follows we direct attention to two aspects of many IWRM influenced water reforms that are important for water grabbing dynamics: (1) decentralisation according to hydrographical boundaries and the involvement of water users water management and (2) the licensing of water abstraction. While these reforms may have contributed to democratising water management in some ways, our purpose here is to show how they can also unwittingly contribute to water grabbing.

\section{Decentralisation of water management}

In the water sector decentralisation in practice means the re-organisation of water governance from administrative units (e.g. districts) to units that coincide with hydrographical boundaries (e.g. basins). This provides an opportunity to deal with the dislocated effects of water use (e.g. pollution). Decentralisation policies and approaches often involve the setting up of Water Users Associations (WUAs) and/or River Basin Organisations (RBOs) which are now important exemplary 'models' in the water sector

The WUA and RBO models include an emphasis on participation of water users in water management. A large body of literature highlights the mixed experiences with user involvement in water management at all levels of governance. ${ }^{108 ; 109 ; 110 ; 111}$ For example, the involvement of users in water management does not prevent strong actors to capture unfair shares of water. Rather, user participation often becomes the forum through which the resource capture is taking shape, often facilitated by excluding the informal, legally not-recognised water users. Kemerink et al. analyse in detail for a case in South Africa how, despite the best of intentions, a policy of user participation in water management through the establishment of a Water Users Association (WUA) is used by the most powerful actors in the catchment to maintain the status quo of a highly unequal water distribution pattern established in the Apartheid era. ${ }^{112}$ Warner et al. refer to various cases of participatory water management in which the process was used as a mechanism to delay decisions to the benefit of vested interests. ${ }^{113}$

More recently participatory processes have come to form the stage of appropriation processes and are used to legitimise water grabbing, though this does not mean that these processes cannot also be used to resist capture. In many countries licences for large-scale land and water investments are subject to an Environmental Impact Assessment (EIA) that includes stakeholder consultations. When investors get 
a license they could be expected to have passed through this stakeholder consultation process. However, these processes are often flawed and end up justifying the investment and silencing further resistance due to the completion of the stakeholder consultation exercises. Examples of such processes with regards to water grabbing have recently been documented for cases in Ghana, ${ }^{114}$ Mozambique, ${ }^{115}$ and Kenya. ${ }^{116}$

\section{Regulation and control through permit systems}

Permit systems are an integral part of IWRM frameworks and have been drawn up in many countries. Van Koppen shows how formal administration-based water rights systems in Sub Saharan Africa have tended to dispossess the informal majority by design, as 'permit systems boil down to the formal dispossession of rural informal water users who manage their water under community-based arrangements' (p.48). Water rights that have historically been arranged locally are now declared subject to formalisation under national law. Existing rights are cancelled-out with the promise to include them in the new law. In practice many of these rights are not (and often cannot) be included in the registration and licensing leading to a weakening of the position of historical smallholder use. Complicated and expensive license application procedures ensure that water permits 'favour the administration-proficient' (p.46). ${ }^{117}$ Dispossession through licensing is a prominent mechanism in the current era of global resource grabs.

Many of the colonial permit systems were designed for dispossessing rural informal water users and van Koppen has argued that recently introduced or revised permit systems, based on such colonial logic, are de facto facilitating water grabs. ${ }^{118}$ Small scale water use, for drinking water and small productive use, is in many systems excluded from licensing, granting it a status of exemption, which according to Hodgson cannot be considered to be a right. ${ }^{119}$ In practice this ignores pluralistic legal systems in which traditional legal systems govern the thousands of smallholders that are deemed uncontrollable under the registration system. ${ }^{120}$ In South Africa general authorisations are exemptions for larger volumes in designated areas. ${ }^{121}$ In Mozambique, these exempted uses are called uso común, or common use, and in Zimbabwe they are referred to as 'primary uses'. ${ }^{122}$ In Islamic law rights to drinking water, formulated as 'rights to thirst' also have a priority. ${ }^{123}$

It is questionable whether these de minimis rights provide any security in practical terms, as this type of 'entitlement cannot lawfully prevent anyone else from also using the resource even if that use affects his own prior use/entitlement' ${ }^{124}$ Formal permits with state backing create first-class rights in comparison to any other right. ${ }^{125}$ The exemption from a need for a permit keeps small-scale users from being registered as users, which makes it easier to overlook them in planning and allocation procedures, as for instance happened in a water grabbing case in Mozambique. ${ }^{126 ; 127 ; 128}$ In Kenya nomadic livestock keepers and fisher folk without formal water licences were dispossessed of their traditional rights when large scale investors started developing the Tana River Delta. ${ }^{129}$ In many cases, smallholders are even aware that their historic agricultural water rights are not recognised in national legal frameworks and that this facilitated water grabbing. A formal right to abstraction of community drinking water does not guarantee that this cannot in practice be dispossessed through a land and water grab. ${ }^{130}$ In Peru smallholder irrigators' formalised water right did not help to protect them against a water grab by a mining company. ${ }^{131}$ In the context of limited registration of smallholder water use, 
poor hydrological knowledge, and/or weak enforcement, permits provide an 'easy way in' for newcomers, while giving them the formal backing of the state. ${ }^{132}$

\section{Growing corporate influence in water management}

We now turn to the growing influence of corporate players in water resources management and water policy debates. ${ }^{133 ; 134 ; 135}$ This is different from privatisation of water supply services which largely concerns urban water provision. Players include transnational corporations (TNCs) who use large volumes of water (to produce beverages, crops and services) that are engaging globally in debates about water management and to protect their access to water supply in the face of growing shortages. The heads of 40 major TNCs recently issued a communiqué to heads of governments calling for decisive action to strengthen 'the enabling environment' for water resources management around the world. ${ }^{136}$ Other groupings include the '2030 Water Resources Group' which is a platform of private sector companies, one international NGO (the World Wide Fund for Nature, WWF), some aid agencies and some national governments (e.g. China, India and Mexico). The 2030 Water Resources Group seeks to play a key role in water resources management at the basin scale, a function that historically is vested with the state. Instruments deployed include information sharing of data of water availability accrued through so called 'water tool risks', a range of convening stakeholders as well as engagement with communities. ${ }^{137}$ However, business interests could triumph over altruistic ones. Water availability data can be framed to serve certain interests and stakeholder engagement may just be very symbolic. Finally, national governments may prioritise business interests and the scope of foreign revenue generation over the local interests and questions of environmental integrity.

Companies are also spearheading innovation and action in water use in the beverages sector. One example is Coca Cola which operates in about 200 countries and has 300 bottling partners. ${ }^{138}$ Coke has set a target to improve water-use efficiency in its plants by $20 \%$ by 2012 against a 2004 baseline. The company claimed in 2010 that it has achieved six years of consecutive reduction along with a $16 \%$ reduction on the 2004 baseline. ${ }^{139}$ But as Box 1 demonstrates there are many contradictions in the way Coke actually operates in-country. 


\section{India}

Across India, movements have emerged against Coca-Cola due to alleged water grabs and water contamination According to local people, Coca-Cola was extracting 1.5 million litres of water per day in a plant located in Plachimada, resulting in a drop in the water table from 150 to 500 feet. Waste deposits from the plant also made the water in the surrounding wells, fields and canals unfit for drinking. The plant was closed on 17 February 2004. This movement triggered new demands against the 87 other Coca-Cola and Pepsi plants in India where water had been depleted and polluted. Coca-Cola claims that these claims are unjustified and points to an independent report undertaken by the Energy and Resources Institute, known as TERI which assessed its practices in India. TERI found the plants to be complying with the government regulations. However, even this report states that Coca-Cola must take into account local community needs since in some plants excesses of bacteria and other pollutants were found (sources: Shiva 2006; Bokaie 2007).

\section{Mexico}

Mexico is currently the number one Coca-Cola consuming nation in the world. The beverage has attained religious significance in places like San Juan Chamula in the state of Chiapas, replacing traditional beverages used in religious ceremonies and used as dowry payment for marriage (Rovira 2000). The company has strong political connections. Vicente Fox, México's former president was the President of the Coca-Cola Corporation of Mexico before coming to power and during his mandate Coca-Cola started to bottle water from water-rich Chiapas and the drink is often handed out for free during local elections by those in power.

However, the main reason for its immense consumption is the lack of potable water, making Mexico the second largest consumer of bottled water, most of which is largely owned by Coca-Cola. Since 2000, CocaCola has been allowed to extract water from 19 aquifers and 15 rivers and also has concessions to dump waste in public water. In 2003, the company paid \$20,000 to compensate for overextracting water while the profits of one bottling plant alone reached \$40,000. (Sources: Bell 2006; Rovira 2000; Wooters 2008)

Box 1: Coca Cola in India and Mexico

The activities of TNCs have largely been welcomed by dominant players in the water sector. In 2012, Pepsico and in 2011, Nestlé controversially won the Stockholm Industry Water Award for leadership, ${ }^{i}$ performance and efforts to improve water management in its supply chain and also for its work with local farmers at the World Water Week in Stockholm, the annual mecca of water experts worldwide.

Nestlé is one of the world's largest corporations involved in food. Like Coke and Pepsico, it has massive structural and bargaining power over the world economy and trade policies including virtual water flows embedded in trade. ${ }^{140}$ Nestlé, like Coca Cola, is playing a leading role in corporate water accountability which includes paying attention to how farmers manage their water and active engagement in various corporate networks around water. ${ }^{141}$ According to Genetic Resources Action International (GRAIN), companies such as Bunge (one of the world's largest agribusiness corporations) are also making direct investments in land as part of the global rush for land. ${ }^{142}$ Pepsico, after winning an award at World Water Week in Stockholm in 2012 for water efficiency (20\% per unit four years ahead of its 2012 goal) announced the next day that it was seeking the right business model to significantly expand operations in Africa and 'thrive in this market of one billion people'. ${ }^{143}$

While some may argue that the growing corporate influence in water management has yet no clear implications for water grabbing, their emerging strategic

\footnotetext{
i The Stockholm Industry Water Award recognizes companies within the business sector that have demonstrated their commitment to advance the world's water situation by achieving impressive performance in their water usage (http://www.siwi.org/prizes/stockholm-industry-water-award).
} 
influence on policy making does have risks and implications for current and future grabbing processes. These include the potential re-allocation of water to the 'highest economic value' having detrimental impacts on local lives, livelihoods and water and food security. Also there is a significant gap between the promotional instruments deployed by companies and what they are actually doing on the ground. The case of Coca Cola illustrates these issues. Despite commitments to 'shared risks' and to sustainable water management, risks are often unequally shared and new water stresses may be created. Furthermore, companies are often more legally bound to be accountable to distant shareholders than to local stakeholders, who are often voiceless and powerless. Due to their structural, bargaining power and influence over global and national policies and processes, they shape and frame powerful discourses, subjecting water governance institutions to processes of capture. ${ }^{144}$

\section{Discussion and Conclusions}

The slippery nature of water grabbing means that it is difficult to pinpoint the effects of reallocations, amongst others, due to surface water/ groundwater interactions and inter-annual variability. These characteristics of water have important implications for those interested in either regulating or contesting them. This may partly help to explain why local communities have reacted in different ways to land and water grabbing. The fluidity of water (and dislocated effects of water grabbing) and 'invisibility' of customary water rights systems can complicate the task of 'framing' water grabbing as really happening and as an injustice warranting a serious and systematic political response. Global governance mechanisms need to address these local complexities as well as two other challenges, namely the (in)visibility of customary access, use and management systems vis-à-vis formal state law; and the complexity of the regulatory field as both plural with overlapping regulatory orders and fragmented (separate state agencies for land vs. water vs. forests vs. fisheries).

As in the land sector, formalisation of rights in the water sector is increasingly seen as a universal solution; but the underlying issue is: formalising what? Rights that have historically been arranged locally are now declared subject to formalisation under national law, and in the context of limited registration of smallholder water use, poor hydrological knowledge, and/or weak enforcement, permits provide an 'easy way in' for newcomers, while giving them the formal backing of the state. ${ }^{145}$ Moreover, some of the security provided by customary arrangements to women and small-holders through informal and kinship arrangements also get eroded, apart from this being a highly bureaucratic process.

Even if formalisation could be a possible 'answer' it can truly only be an effective answer if what is being 'formalised' is water as a human right, prioritising the wellbeing and livelihoods of the poor, marginalised and vulnerable with regard to access, use and control. As has been noted, the human right to water was the result of decades of intense global struggle and lobbying, and this official recognition was a great victory for the global water justice movement. But so far debates around the right to water have had very limited effect on water resource management and in the mainstream have very narrowly been interpreted as the right to safe drinking water, neglecting the need for productive uses of water. The Special Rapporteur for the Right to Water and Sanitation also seems to under-serve the cause of human rights by claiming that rights are market-neutral and by remaining agnostic. Instead, human rights need to be actively used as a counter-veiling force against commodification. 
Here we are calling for both a stronger social justice perspective to the right to water as well as a broader definition of the human right to water, encompassing both domestic and productive uses so integral for survival and wellbeing.

In this article we explored the significance of global land and water governance initiatives for water grabbing at the national and local level. We demonstrated how disparate and seemingly isolated global processes have led to a domination of neoliberal discourses and trends. In the field of water management it is exemplary that the Dublin conference became the most important watershed moment and thus won out over earlier processes such as Delhi in which there was a stronger focus on equity and universality. The Dublin declaration and its popularity reflect the dominant Washington Consensus of the 1990s which also influenced environmental governance. In water management, this has led to clear neoliberal tendencies, elaborated alongside policies of integration, participation, water rights formalisation and basin management. After privatisation of water services now privatisation and financialisation of the resource itself is taking place. Similar to IWRM policies, with its 20-year-old roots, new trends, such as drawing attention to the food-energy-water nexus, reinforce a call for integrated governance while at the same time legitimising increased corporate involvement. Fuzzy and ambiguous processes of global water and land governance are thus increasing local level uncertainties and complexities. Usually powerful players can navigate their ways through such uncertainties, making them into mechanisms of exclusion for poor and marginalised people.

For less powerful players, resolving ambiguities in conflicting regulatory frameworks may require tipping the balance toward the most favourable one. This may not be as impossible as it might seem. As Margulies et al. point out, politicalinstitutional uncertainties in global governance can also potentially become opportunities for previously excluded actors and ideas to be heard and make an impact, by creating unexpected '... opportunities for policy entrepreneurs and new ideas to enter global policy spaces that may set governance along new pathways'. ${ }^{146}$

How to convert this potential into actual gains from a social justice perspective is a big challenge. When understood as the capturing of control not just of the water itself, but also of the power to decide how this will be used and by whom, water grabbing is a potentially powerful entry point for increasing contestation and building resistance to the neoliberal corporate business led convergence in global resource governance discourses and processes. Control grabbing is perhaps best seen as a contingent process, marked by conflict, negotiation, friction, that can end up ratifying an existing balance of power. Although poor people often do lose out, under certain conditions, their political action can make a positive difference. Yet compared to land grabbing, water grabbing appears today relatively less contested from an equity and water justice perspective, much less an agrarian justice and environmental justice perspective, even though the materiality of water means that water grabbing potentially affects greater numbers of diverse water users. If done systematically, applying a water lens to grabbing situations can help to open up vistas for possible political action that has the potential to challenge dominant governance processes:

a. Far-reaching spillover effects of specifically water grabbing widens the space/time field of impacts, suggests the value of and need for more systematic horizontal and vertical alliance-building amongst affected people. There is a need to go beyond the fixation with water volumes to focus on issues of access, quality, timing and control.

b. Water has crucial importance for sustaining human life, which makes that grabbing of land and water potentially affects all kinds of users directly in 
their sustenance of life. This reinforces the need to build alliances across land and water sectors.

It is unlikely that such a perspective will just simply materialise on its own; social pressure and strategic political action is needed. The human right to food may also have potential as a basis for organising strategic political action and building cross-class and multi-sectoral alliances, similar to how it has served as an important focal point for agrarian justice and land rights activism. For whatever problems there are with the FAO-TGs, they can potentially still be used to pressure governments, since water is indeed deeply and inextricably interconnected with the other natural resources that are covered (land, fisheries and forests) and which are framed in the context of food security and the right to food.

Finally, our analysis points to a need for land and water rights advocates to begin more systematic engagements with each other around elaborating a human right to land and water that can off-set or build counterweights to the neoliberal corporate business led convergence we are seeing in global resource governance discourses and processes, which are imposing views of land and water as tradable economic assets. This would mean elaborating a human rights perspective to land and to water that is both more interconnected, more social justice oriented and encompasses productive uses of water. 


\section{Notes}

${ }^{1}$ For an overview of the discussion of this convergence of factors see B White, S.M. Borras Jr, R Hall, I Scoones \& W Wolford, 'The new enclosures: Critical perspectives on corporate land deals', Journal of Peasant Studies, 39(3-4), 2012, pp. 619-647.

${ }^{2}$ L Mehta, G.J. Veldwisch, and J Franco, 'Introduction to the Special Issue: Water grabbing? Focus on the (re) appropriation of finite water resources', Water Alternatives, 5(2), 2012, pp. 193-207.

${ }^{3} \mathrm{P}$ Woodhouse, 'New investment, old challenges. Land deals and the water constraint in African agriculture', Journal of Peasant Studies, 39(3-4), 2012, pp. 777-794.

${ }^{4}$ J Skinner and L Cotula, Are land deals driving 'water grabs'? Briefing: The global land rush, London: International Institute for Environment and Development (IIED), 2011, http://pubs.iied.org/17102IIED (accessed April 2012).

${ }^{5}$ A.Y Hoekstra and M.M. Mekonnen, 'The water footprint of humanity', Proceedings of the National Academy of Sciences, 109(9), 2012, pp. 3232-3237.

${ }^{6}$ World Bank, Rising Global Interest in Farmland: Can it yield sustainable and equitable results?', Washington DC: World Bank, 2010.

${ }^{7} \mathrm{~J}$ Chu, 'A blue revolution for Africa? Large-scale irrigation projects and land and water 'grabs", in Allan, T et al (eds.), Handbook of land and water grabs in Africa: Foreign direct investment and food and water security. Routledge, 2012, pp. 207-220.

${ }^{8}$ T Hertzog, A Adamczewski, F Molle, J.C. Poussin, \& J.Y. Jamin, 'Ostrich-like strategies in sahelian sands? Land and water grabbing in the Office du Niger, Mali’, Water Alternatives, 5(2), 2012, pp. 304321.

${ }^{9}$ Woodhouse, 'New investment, old challenges'

${ }^{10}$ S Duvail, C Médard, O Hamerlynck, \& D.W. Nyingi, 'Land and water grabbing in an East African coastal wetland: the case of the Tana Delta', Water Alternatives, 5(2), 2012, pp. 322-343.

${ }^{11}$ T.O Williams, B Gyampoh, F Kizito, \& R Namara, 'Water Implications of Large-Scale Land Acquisitions in Ghana', Water Alternatives, 5(2), 2012, pp. 243-265.

12 M Islar, 'Privatised Hydropower Development in Turkey: A Case of Water Grabbing?', Water Alternatives, 5(2), 2012, pp. 376-391.

13 M Sosa, \& M Zwarteveen, 'Exploring the politics of water grabbing: The case of large mining operations in the Peruvian Andes', Water Alternatives, 5(2), 2012, pp. 360-375.

14 Mehta, Veldwisch and Franco, 'Introduction to the Special Issue'.

15 Ibid.

${ }^{16}$ World Bank, Rising Global Interest in Farmland.

${ }^{17}$ Oxfam, Land and power: The growing scandal surrounding the new wave of investments in land. Oxford: Oxfam-International, 2011.

${ }^{18}$ S. Borras, Jr., J Franco, S Gomez, C Kay, and M Spoor, 'Land grabbing in Latin America and the Caribbean', Journal of Peasant Studies, 39(3-4), 2012, pp. 845-72.

${ }^{19}$ M.C. Rulli, A Saviori and P D’Odorico, 'Global land and water grabbing', Proceedings of the National Academy of Sciences, 110(3), 2013, pp. 892-897.

${ }^{20}$ Hertzog, Adamczewski, Molle, Poussin, Jamin, 'Ostrich-like strategies in sahelian sands?'

${ }^{21}$ S.M Borras Jr, D Fig, \& S.M Suárez, 'The politics of agrofuels and mega-land and water deals: insights from the ProCana case, Mozambique', Review of African Political Economy, 38(128), 2011, pp. 215-234.

${ }^{22}$ S Borras, Jr. and J.C. Franco, 'From Threat to Opportunity? Problems with the Idea of a 'Code of Conduct' for Land-Grabbing', Yale Human Rights and Development Law Journal, 13(2), 2010, pp. 507-523.

${ }^{23}$ Williams, Gyampoh, Kizito \& Namara, 'Water Implications of Large-Scale Land Acquisitions in Ghana'. 
${ }^{24}$ A Bues, \& I Theesfeld, 'Water grabbing and the role of power: Shifting water governance in the light of agricultural foreign direct investment', Water Alternatives, 5(2), 2012, pp. 266-283.

${ }^{25}$ A Houdret, 'The Water Connection: Irrigation, Water Grabbing and Politics in Southern Morocco', Water Alternatives, 5(2), 2012, pp. 284-303.

${ }^{26}$ Duvail, Médard, Hamerlynck \& Nyingi, 'Land and water grabbing in an East African coastal wetland'.

${ }^{27}$ I Velez Torres, 'Water grabbing in the Cauca basin: the capitalist exploitation of water and dispossession of afro-descendant communities', Water Alternatives, 5(2), 2012, pp. 421-449.

${ }^{28}$ L. A Wily, 'Enclosure revisted: putting the global land rush in historical perspective', in T Allan T, et al (eds.) Handbook of land and water grabs in Africa: Foreign direct investment and food and water security, Routledge, 2013, pp. 11-24.

${ }^{29} \mathrm{~S}$ Wagle, S Warghade, \& M Sathe, 'Exploiting policy obscurity for legalising water grabbing in the era of economic reform: The case of Maharashtra, India', Water Alternatives, 5(2), 2012, pp. 412-430.

${ }^{30}$ D Bossio, T Erkossa, Y Dile, M McCartney, F Killiches, \& H Hoff, 'Water implications of foreign direct investment in Ethiopia's agricultural sector', Water Alternatives, 5(2), 2012, pp. 223-242.

${ }^{31} \mathrm{~N}$ Matthews, 'Water Grabbing in the Mekong Basin - An Analysis of the Winners and Losers of Thailand's Hydropower Development in Lao PDR', Water Alternatives, 5(2), 2012, pp. 392-411.

${ }^{32}$ Duvail, Médard, Hamerlynck \& Nyingi, 'Land and water grabbing in an East African coastal wetland'.

${ }^{33}$ Hertzog, Adamczewski, Molle, Poussin, Jamin, 'Ostrich-like strategies' in sahelian sands?'

${ }^{34}$ Williams, Gyampoh, Kizito \& Namara, 'Water Implications of Large-Scale Land Acquisitions in Ghana'.

${ }^{35}$ Islar, 'Privatised Hydropower Development in Turkey'.

${ }^{36}$ Wagle, Warghade and Sathe, 'Exploiting policy obscurity for legalising water grabbing'.

${ }^{37}$ Bues and Theesfeld, 'Water grabbing and the role of power.'

${ }^{38}$ Bossio, Erkossa, Dile, McCartney, Killiches, \& Hoff, 'Water implications of foreign direct investment'.

${ }^{39}$ Duvail, Médard, Hamerlynck \& Nyingi, 'Land and water grabbing in an East African coastal wetland'.

${ }^{40}$ Matthews, 'Water Grabbing in the Mekong Basin'.

${ }^{41}$ Wagle, Warghade and Sathe, 'Exploiting policy obscurity for legalising water grabbing'.

${ }^{42}$ Velez Torres, 'Water grabbing in the Cauca basin'.

${ }^{43}$ Sosa \& Zwarteveen, 'Exploring the politics of water grabbing'.

${ }^{44}$ Hertzog, Adamczewski, Molle, Poussin, Jamin, 'Ostrich-like strategies in sahelian sands?'

${ }^{45}$ Williams, Gyampoh, Kizito \& Namara, 'Water Implications of Large-Scale Land Acquisitions in Ghana'.

${ }^{46}$ Matthews, 'Water Grabbing in the Mekong Basin'.

${ }^{47}$ Woodhouse, 'New investment, old challenges'.

${ }^{48} \mathrm{P}$ Woodhouse and A.-S Ganho, Is water the hidden agenda of agricultural land acquisition in subSaharan Africa? International Conference on Global Land Grabbing, Institute of Development Studies and Future Agricultures Consortium, University of Sussex, UK, 6-8 April 2011.

${ }^{49}$ Skinner and Cotula, Are land deals driving 'water grabs'?

${ }^{50}$ Sosa \& Zwarteveen, 'Exploring the politics of water grabbing'.

${ }^{51}$ Velez Torres, 'Water grabbing in the Cauca basin'.

${ }^{52}$ Matthews, 'Water Grabbing in the Mekong Basin'.

${ }^{53}$ Wagle, Warghade and Sathe, 'Exploiting policy obscurity for legalising water grabbing'. 
${ }^{54} \mathrm{~S}$ Gasteyer, J Isaac, J Hillal and S Walsh, 'Water grabbing in Colonial Perspective: Land and Water in Israel/Palestine', Water Alternatives, 5(2), 2012, pp.450-468.

${ }^{55}$ Islar, 'Privatised Hydropower Development in Turkey'.

${ }^{56}$ Duvail, Médard, Hamerlynck \& Nyingi, 'Land and water grabbing in an East African coastal wetland'.

${ }^{57}$ Matthews, 'Water Grabbing in the Mekong Basin'.

${ }^{58}$ Williams, Gyampoh, Kizito \& Namara, 'Water Implications of Large-Scale Land Acquisitions in Ghana'.

${ }^{59}$ Duvail, Médard, Hamerlynck \& Nyingi, 'Land and water grabbing in an East African coastal wetland'.

${ }^{60} \mathrm{~W}$ Beekman, \& G.J Veldwisch, 'The evolution of the land struggle for smallholder irrigated rice production in Nante, Mozambique'. Physics and Chemistry of the Earth, Parts A/B/C, 2012.

${ }^{61}$ Velez Torres, 'Water grabbing in the Cauca basin'.

${ }^{62}$ Gasteyer, Isaac, Hillal and Walsh, 'Water grabbing in Colonial Perspective'.

${ }^{63}$ Houdret, 'The Water Connection'.

${ }^{64}$ Sosa \& Zwarteveen, 'Exploring the politics of water grabbing'.

${ }^{65}$ S.M Borras, J.C Franco and C Wang, 'The Challenge of Global Governance of Land Grabbing: Changing International Agricultural Context and Competing Political Views and Strategies', Globalizations, 10(1), 2013, pp. 161-179.

${ }^{66}$ Mehta, Veldwisch and Franco, 'Introduction to the Special Issue'.

${ }^{67} \mathrm{~S}$ Arduino, G Colombo, O.M Ocampo, \& L Panzeri, 'Contamination of community potable water from land grabbing: A case study from rural Tanzania', Water Alternatives, 5(2), 2012, pp. 344-359.

${ }^{68}$ Sosa \& Zwarteveen, 'Exploring the politics of water grabbing'.

${ }^{69}$ L Mehta et al. Exploring Understandings of Institutions and Uncertainty. New Directions in Natural Resources Management. IDS Discussion Paper 372. Brighton, 1999, p.10.

${ }^{70}$ S.M Suárez, 'The Human Rights Framework in Contemporary Agrarian Struggles', Journal of Peasant Studies, 40(1), 2013, pp. 239-290.

${ }^{71}$ P Seufert, 'The FAO Voluntary Guidelines on the Responsible Governance of Tenure of Land, Fisheries and Forests', Globalizations, 10(1), 2013, pp. 181-186.

${ }^{72}$ S.M Suarez, The Recently Adopted Guidelines on the Responsible Governance of Tenure of Land, Fisheries and Forests: A Turning Point in the Governance of Natural Resources? Right to Food and Nutrition Watch 2012 -- Who Decides About Global Food and Nutrition? Strategies to Regain Control. Bread for the World, FIAN International, and Interchurch Organization for Development Cooperation (ICCO), 2012, p.37.

${ }^{73}$ R Künnemann \& S.M Suárez, 'International Human Rights and Governing Land Grabbing: A View from Global Civil Society', Globalizations, 10(1), 2013, pp. 123-139.

${ }^{74}$ Borras, Jr. and Franco, 'From Threat to Opportunity?'.

${ }^{75} \mathrm{R}$ Bustamante, C Crespo and A Walnycki, 'Seeing through the Concept of Water as a Human Right in Bolivia', in F Sultana and A Loftus (eds.) The Right to Water: Politics, Governance and Social Struggles. Earthscan, London, 2011, pp. 223-240.

${ }^{76} \mathrm{~L}$ Mehta, Unpacking rights and wrongs: do human rights make a difference? The case of water rights in India and South Africa. IDS Working Paper 260, 2005.

${ }^{77}$ Office of the High Commissioner for Human Rights (OHCHR), Report of the independent expert on the issue of human rights obligations related to access to safe drinking water and sanitation', A/HRC/15/31, Office of the United Nations High Commissioner for Human Rights, Geneva, 2010.

${ }^{78} \mathrm{~J}$ Sumberg, J Thompson and P Woodhouse, 'Why agronomy in the developing world has become contentious', Agriculture and Human Values, 30(1), 2013, pp. 71-83.

${ }^{79} \mathrm{~K}$ Conca, Governing water: Contentious transnational politics and global institution building, 
Cambridge, MA: MIT Press, 2006.

$80 \mathrm{ibid}$

${ }^{81}$ J. A Allan, M Keulertz, S Sojamo, \& J Warner (eds.), Handbook of land and water grabs in Africa: Foreign direct investment and food and water security. Routledge, 2013.

${ }^{82}$ A.K Chapagain and D Tickner, 'Water footprint: Help or hindrance?', Water Alternatives, 5(3), 2012, pp. 563-581.

${ }^{83}$ A.Y Hoekstra, Water Footprint of Modern Consumer Society, Taylor and Francis Group, 2013, p. 288.

${ }^{84}$ N.D Hepworth, J.C Postigo, B Güemes Delgado and P Kjell, Drop by drop: Understanding the impacts of the UK's water footprint through a case study of Peruvian asparagus. Progressio, CEPES and Water Witness International, 2010.

${ }^{85}$ D Harvey, The new imperialism, Oxford: Oxford University Press, 2003.

${ }^{86} \mathrm{~K}$ Bakker, 'Neoliberalizing Nature? Market environmentalism in water supply in England and Wales', Annals of the Association of American Geographers, 95(3), 2005, pp. 542-65.

${ }^{87}$ Borras, Franco, Gomez, Kay and Spoor, 'Land grabbing in Latin America.'

${ }^{88} \mathrm{~S}$ Bernstein, The compromise of liberal environmentalism, Columbia University Press, New York, 2001.

${ }^{89} \mathrm{~K}$ Bakker, 'Neoliberalizing Nature? Market environmentalism in water supply in England and Wales', Annals of the Association of American Geographers, 95(3), 2005, pp. 542-65.

${ }^{90}$ A Nicol, L Mehta and J Allouche (eds), 'Some for All?' Politics and Pathways in Water and Sanitation, IDS Bulletin 43(2), 2012.

${ }^{91}$ L Mehta, (edited volume) The Limits to Scarcity, London: Earthscan, 2010.

92 Beekman \& Veldwisch, 'The evolution of the land struggle for smallholder irrigated rice production in Nante, Mozambique'

${ }^{93}$ Boelens \& Vos, 'The danger of naturalizing water policy concepts: Water productivity and efficiency discourses from field irrigation to virtual water trade', Agricultural Water Management 108, 2012, pp.16-26.

${ }^{94}$ R.M. Friend, 'Fishing for influence: fisheries science and evidence in water resources development in the Mekong basin', Water Alternatives 2(2), 2009, pp. 167-182.

${ }^{95}$ Duvail, Médard, Hamerlynck \& Nyingi, 'Land and water grabbing in an East African coastal wetland'.

${ }^{96}$ M Finger and Allouche J, Water Privatisation: Transnational Corporations and the Re-regulation of the Global Water Industry, London and New York: Taylor and Francis, 2002.

${ }^{97}$ Finger and Allouche, Water Privatisation.

${ }^{98}$ K.J Bakker, Privatizing water: governance failure and the world's urban water crisis. Cornell University Press, 2010.

${ }^{99}$ D Hall, E Lobina and R de la Motte, 'Public resistance to privatisation in water and energy', Development in Practice, 15(3-4), 2005, pp. 286-301.

${ }^{100}$ A Tricarico and C Amicucci, 'Background on financialisation of water', paper prepared by CRBM for the European meeting "For the construction of the European Network for Public Water", Naples, 10-11 December, 2012.

${ }^{101}$ F Molle, 'Nirvana concepts, narratives and policy models: Insights from the water sector', Water Alternatives, 1(1), 2008, pp. 131-156.

102 Ibid .

${ }^{103}$ Global Water Partnership, Integrated Water Resources Management, TAC Background Papers no. 4, Stockholm: Global Water Partnership, 2000.

${ }^{104}$ A.K Biswas, 'Integrated Water Resources Management: A Reassessment', Water International, 29(2), 2004, pp. 248-256. 
${ }^{105}$ Conca, Governing water: Contentious transnational politics and global institution building.

${ }^{106}$ Molle, 'Nirvana concepts, narratives and policy models'.

${ }^{107}$ Ibid .

${ }^{108} \mathrm{~F}$ Cleaver, 'Paradoxes of participation: questioning participatory approaches to development', Journal of International Development, 11(4), 1999, pp. 597-612.

${ }^{109}$ P Wester, D.J. Merrey, \& M De Lange, 'Boundaries of consent: Stakeholder representation in river basin management in Mexico and South Africa', World Development, 31(5), 2003, pp. 797-812.

${ }^{110} \mathrm{R}$ Boelens, The rules of the game and the game of the rules: Normalization and resistance in Andean water control, Wageningen: Wageningen University, 2008.

${ }^{111} \mathrm{~J}$ Warner, P Wester \& A Bolding, 'Going with the flow: river basins as the natural units for water management', Water Policy, 10(S2), 2008, pp. 121-138.

112 J. S Kemerink, L.E. Méndez, R Ahlers, P Wester, \& P van der Zaag, 'The question of inclusion and representation in rural South Africa: challenging the concept of water user associations as a vehicle for transformation', Water Policy, 15(2), 2013, pp. 243-257.

${ }^{113}$ Warner, Wester \& Bolding, 'Going with the flow'.

${ }^{114}$ Williams, Gyampoh, Kizito \& Namara, 'Water Implications of Large-Scale Land Acquisitions in Ghana'.

${ }^{115}$ Borras, Franco, Gomez, Kay and Spoor, 'Land grabbing in Latin America.'

${ }^{116}$ Duvail, Médard, Hamerlynck \& Nyingi, 'Land and water grabbing in an East African coastal wetland'.

${ }^{117}$ B van Koppen, Dispossession at the interface of community-based water law and permit systems', Community-based Water Law and Water Resource Management Reform in Developing Countries, 46, 2007.

${ }^{118}$ Ibid.

${ }^{119}$ S Hodgson, Land and water: the rights interface (Vol. 84), Food \& Agriculture Organisation, p.92, 2004.

${ }^{120} \mathrm{R}$ Meinzen-Dick, \& L Nkonya, 'Understanding legal pluralism in water rights: Lessons from Africa and Asia', in African Water Laws Workshop: Plural Legislative Frameworks for Rural Water Management in Africa, 2005.

${ }^{121}$ van Koppen, Sally, Aliber, Cousins \& Tapela, Water resources management, rural redress and agrarian reform, Working Paper Series No. 7.

${ }^{122}$ G.J. Veldwisch, W Beekman \& A Bolding, 'Smallholder Irrigators, Water Rights and Investments in Agriculture: Three Cases from Rural Mozambique', Water Alternatives, 6(1), 2013, pp. 125-141.

${ }^{123}$ Meinzen-Dick \& Nkonya, Understanding legal pluralism in water rights.

${ }^{124}$ Hodgson, Land and water: the rights interface.

${ }^{125}$ van Koppen, Dispossession at the interface of community-based water law and permit systems, 46.

${ }^{126} \mathrm{P}$ van der Zaag, D Juizo, A Vilanculos, A Bolding, \& N.C. Post Uiterweer. 'Does the Limpopo River Basin have sufficient water for massive irrigation development in the plains of Mozambique?', Physics and Chemistry of the Earth, Parts A/B/C, 35(13), 2010, pp. 832-837.

${ }^{127}$ Borras, Franco, Gomez, Kay and Spoor, 'Land grabbing in Latin America.'

${ }^{128}$ Veldwisch, Beekman \& Bolding, 'Smallholder Irrigators, Water Rights and Investments in Agriculture'.

${ }^{129}$ Duvail, Médard, Hamerlynck \& Nyingi, 'Land and water grabbing in an East African coastal wetland'.

${ }^{130}$ Arduino, Colombo, Ocampo \& Panzeri, 'Contamination of community potable water'.

${ }^{131}$ Sosa \& Zwarteveen, 'Exploring the politics of water grabbing'.

132 Van Koppen, Dispossession at the interface of community-based water law and permit systems. 
${ }^{133}$ N.D Hepworth, 'Open for business or opening Pandora's box? A constructive critique of corporate engagement in water policy: An introduction', Water Alternatives, 5(3), 2012, pp. 543-562.

${ }^{134} \mathrm{P}$ Newborne and $\mathrm{N}$ Mason, 'The private sector's contribution to water management: Re-examining corporate purposes and company roles', Water Alternatives, 5(3), 2012, pp. 603-618.

${ }^{135} \mathrm{~S}$ Sojamo and E.A Larson, 'Investigating food and agribusiness corporations as global water security, management and governance agents: The case of Nestlé, Bunge and Cargill', Water Alternatives, 5(3), 2012, pp. 619-635.

${ }^{136}$ Newborne and Mason, 'The private sector's contribution to water management'.

${ }^{137}$ Ibid.

${ }^{138}$ Ibid, p.610.

${ }^{139}$ Ibid.

${ }^{140}$ Sojamo and Larson, 'Investigating food and agribusiness corporations'.

${ }^{141}$ Ibid.

${ }^{142}$ Genetic Resources Action International (GRAIN), Land Grabs Data Set, 2012,

http://www.grain.org/article/entries/4479-grain-releases-data-set-with-over-400-global-land-grabs (accessed 23 August 2013).

${ }^{143}$ Newborne and Mason, 'The private sector's contribution to water management'.

${ }^{144}$ Sojamo and Larson, 'Investigating food and agribusiness corporations'.

${ }^{145}$ Van Koppen, Dispossession at the interface of community-based water law and permit systems'.

${ }^{146}$ M.E. Margulis \& T Porter, 'Governing the Global Land Grab: Multipolarity,

Ideas, and Complexity in Transnational Governance', Globalizations, 10(1), 2013, p.68. 